\title{
The Polish road to the new European Green Deal - challenges and threats to the national energy policy
}

AbSTRACT: The European Union aspires to pursue an ambitious climate policy. The energy sector is a key tool to ensure success in this area. At the same time, excessively ambitious targets can be a serious problem for individual member states. The aim of the article is to analyze the possibilities available to the Polish energy sector in the context of the assumed EU climate neutrality goals by 2050 .

The analyzed research problem concerns, in particular, two areas of strategic importance for Poland: the coal sector and the renewable energy sources sector. The role of the former should be significantly reduced in the coming decades, while the position of the latter should be substantially strengthened. The juxtaposition of these challenges with the Polish economic, social and technological realities is the main subject of analysis in this text. The method of system analysis with elements of a decision-making approach will be used. This will allow for an effective analysis and review at the research level of the most important problems and challenges faced by Poland in light of the necessary adjustments to be made in order to achieve the priorities assumed by the European Union.

The hypothesis of the article is that Poland is able to effectively meet European climate targets, although the implementation of this challenge requires decisive action on the part of the government,

$\triangle$ Corresponding Author: Krzysztof Tomaszewski; e-mail: k.tomaszewski3@uw.edu.pl

1 Faculty of Political Science and International Studies, University of Warsaw, Poland; ORCID iD: 0000-00026324-1827; e-mail: k.tomaszewski3@uw.edu.pl

2020. The Author(s). This is an open-access article distributed under the terms of the Creative Commons Attribution-ShareAlike International License (CC BY-SA 4.0, http://creativecommons.org/licenses/by-sa/4.0/), which permits use, distribution, and reproduction in any medium, provided that the Article is properly cited. 
as well as an adequate response from investors and society. To this end, appropriate actions must be undertaken at both a strategic and operational level.

KEYWORDS: EU Green Deal, energy policy, coal, renewable energies, coronavirus

\section{Introduction}

The European Union has consistently implemented environmental and climate protection measures. The energy policy is a key tool for achieving the ambitious priorities set by the European Commission (hereinafter referred to as: EC) headed by Ursula von der Leyen. The objectives set out in the "European Green Deal" communication are not only an extension of the existing priorities contained in the Paris Agreement, but also a significant step forward (EC 2019). It will enable the European Union to achieve climate neutrality by 2050.

These assumptions, which are undoubtedly correct from an ideological point of view, must, however, be confronted with the political, economic and social circumstances existing in the member states. It is certain that the European economy, weakened by the coronavirus crisis, will need strong pro-development impulses to avoid stagnation and, consequently, negative economic growth. The key question in this situation is: will climate issues also remain a priority for member states? Fostering an expensive energy transition seems a difficult challenge. Its implementation can demand considerable effort on the part of European countries and societies.

This dilemma also remains a significant problem for Poland. Actually achieving climate neutrality objectives would mean that two key changes in the Polish energy policy must be introduced: 1) decreasing the use of hard coal and lignite in energy production, and 2) increasing the use of renewable energy sources in the national energy balance. This is the research assumption of this article.

The aim of this article is to analyze to what extent the above challenges are feasible in the time perspective indicated by the European Union, and in the light of horizontal strategies adopted by the Polish government. A method of system analysis with elements of a decision-making approach will be used.

The subject literature includes numerous studies on the energy and climate policy of the European Union and the long-term energy policy of Poland. They were undertaken both by researchers from the area of sciences and social sciences (Młynarski 2019; Gawlik and Mokrzycki 2019; Tomaszewski 2018; Rosicki 2017; Morris and Jungjohann 2016; Mrozowska 2016; Ruszel 2016; Gawlik et al. 2015; Księżopolski 2015).

The problems and research questions indicated above need to be reassessed. This is particularly important, taking the most recent challenges presented to Member States by the European Commission under the supervision of Ursula von der Leyen, as well as the new economic circumstances, such as the epidemic situation in Poland, Europe and the world, into account. 


\section{Reducing coal in the Polish energy sector - from debate to action}

Coal plays an ambivalent role in the Polish power industry. On the one hand, it is a strategic energy resource of key importance from the point of view of Poland's economic security (Nyga-Łukaszewska et al. 2020). As described in "Poland's Energy Policy until 2030" (PEP 2030) of November 10, 2009, coal is considered a source that is an important stabilizer for the national energy and economy.

On the other hand, such a structure of energy generation (see Fig. 1) places Poland among the largest anthropogenic emitters of greenhouse gases in the European Union.

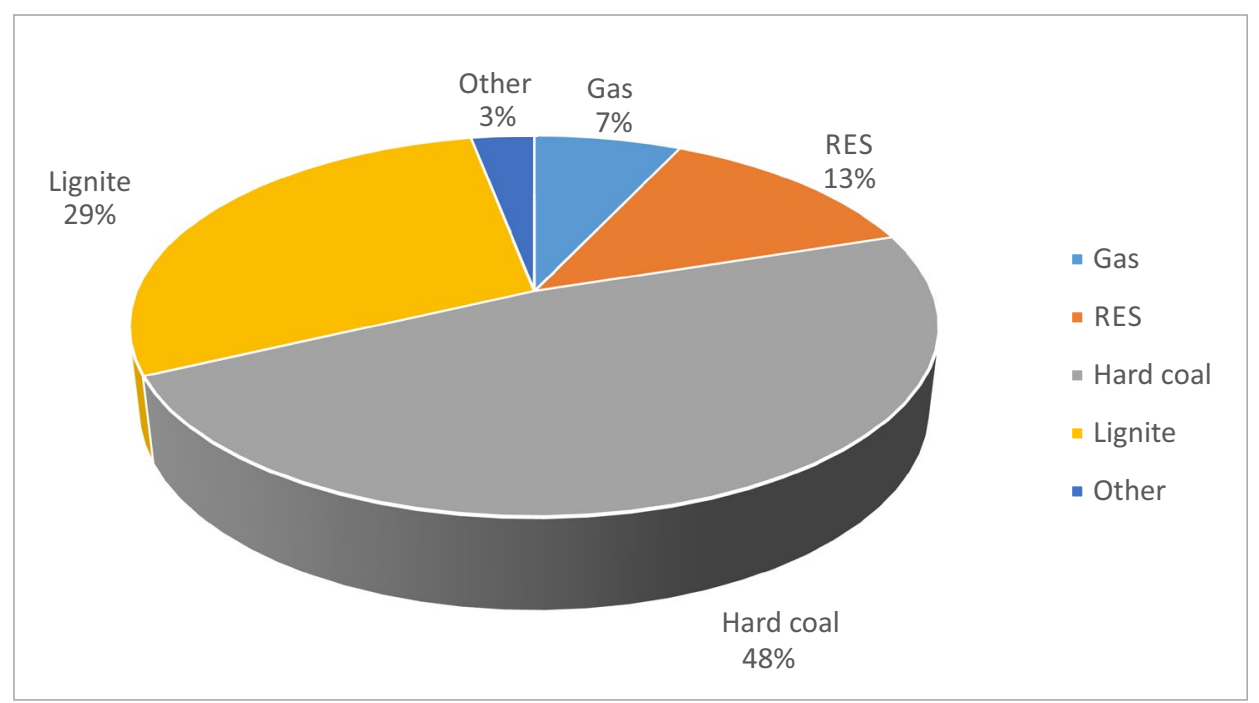

Fig. 1. Structure of electricity production by carriers in 2018

Source: based on the NECP 2019

Rys 1. Struktura produkcji energii elektrycznej wg nośników w 2018 r.

Analyzing the above thesis from a statistical point of view, the situation of the Polish energy sector is described unfavorably. As indicated by the Supreme Audit Office (hereinafter referred to as: NIK), in 2018, Poland was the sixth largest electricity consumer in the EU. It was also the second country in the EU (after Germany) in terms of generating electricity based on hard coal $(80 \mathrm{TWh})$ and lignite (49 TWh). At the same time, Poland was also the only country in the EU where there was an increase in generation based on hard coal (by 2 TWh) (NIK 2019). 
The Polish economy ranks second (after the Estonian economy) in terms of emissions. In 2018 , average emissions reached $682 \mathrm{gCO} 2 \mathrm{eq} / \mathrm{kWh}$ (grams of carbon dioxide equivalent of a kilowatt hour of electricity generation) and had increased by $1 \%$ compared to 2017. The EU average at that time amounted to $296 \mathrm{gCO} 2 \mathrm{eq} / \mathrm{kWh}$ and was 5\% lower compared to 2017 (NIK 2019).

In social terms, this situation is perceived negatively by citizens. The society is increasingly aware of environmental and climate issues. These problems are publicized by the media and thus constantly present in public discourse. This has a strong impact on increasing eco-friendly attitudes (Devine-Wright 2019).

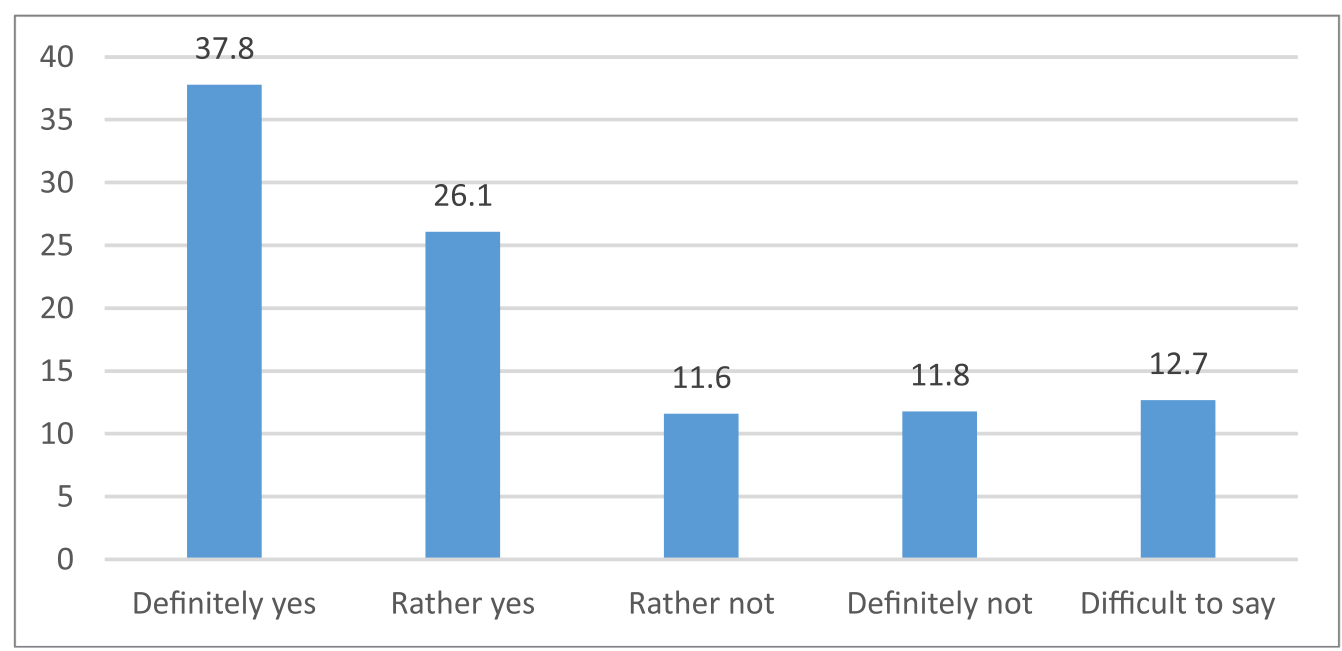

The study was conducted using the CATI method on a sample of 1,100 people (data given as a percentage).

Fig. 2. Should Poland abandon coal-based power generation to reduce greenhouse gas emissions? Source: study based on United Surveys for RMF FM and Dziennik Gazeta Prawna

Rys. 2. Czy Polska powinna zrezygnować z energetyki opartej na węglu, aby zmniejszyć emisję gazów cieplarnianych do atmosfery?

With this in mind, studies also show that citizens are willing to pay higher energy bills in order to reduce the negative environmental impact of the energy sector. This position of the respondents demonstrates that pro-ecological views are strengthened by a behavioral factor (Cohen et al. 2014; Marczuk 2014). The expectations related to the reduction of coal in the country's energy balance are followed by a readiness to bear the additional costs associated with energy transition.

As a counterpoint, it should be noted that there are positive changes in the shape of the Polish energy mix, though the process still seems too slow. In the years 2012-2018, the total share of energy produced from coal in the Polish mix decreased from 87.63 to $79.56 \%$. A decrease in the share of cumulative production in this period was mainly observed in lignite - a decrease of 5.07 percentage points (NIK 2019). 


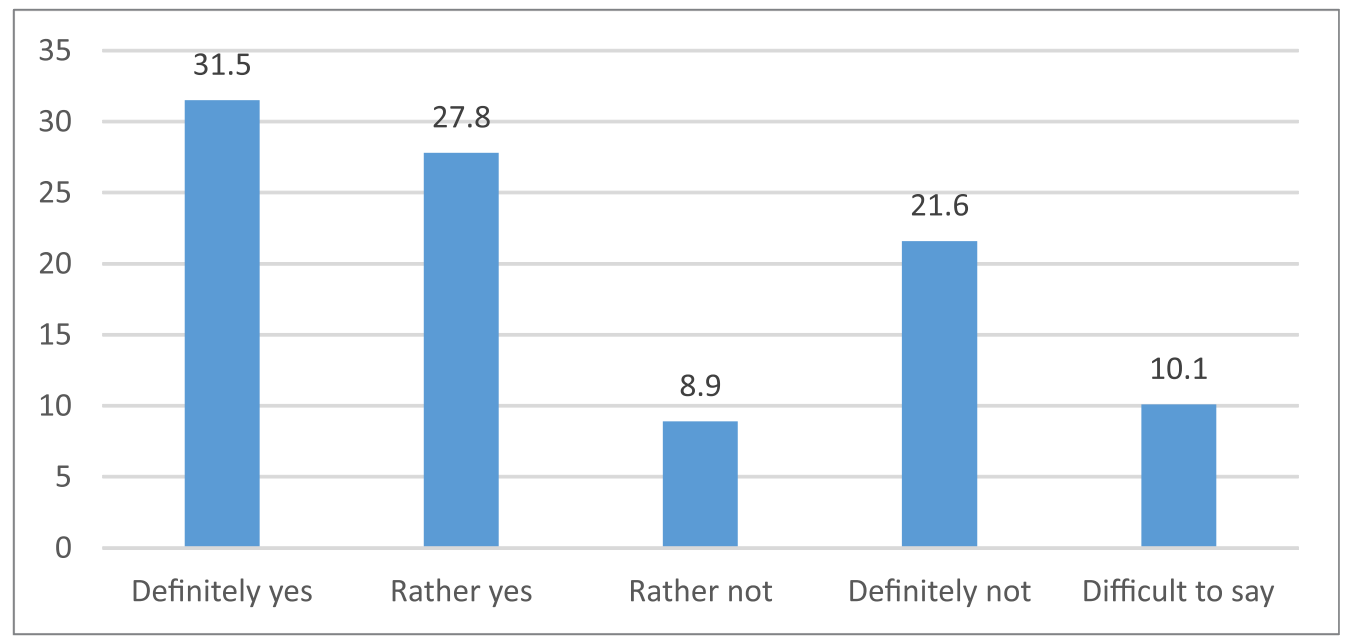

The study was conducted using the CATI method on a sample of 1,100 people (data given as a percentage).

Fig. 3. In order to halt climate change, would you agree to increase the cost of heating/energy to replace coal with other less polluting fuels?

Source: study based on United Surveys for RMF FM and Dziennik Gazeta Prawna

Rys. 3. Czy w celu powstrzymania zmian klimatycznych zgodziłby się Pan/Pani na podwyżkę kosztów ogrzewania/ energii, aby zastąpić węgiel innymi paliwami, które emitują mniej zanieczyszczeń?

When discussing the strategic dimension, it should be noted that, in the draft of Poland's Energy Policy until 2040 (PEP 2040) of November 8, 2019, developed by the Ministry of Energy, no new coal-fired power plants are planned to be built (except for the already advanced projects - Jaworzno, Opole and Ostrołęka). From a climate protection point of view, this is certainly good news. It may prove that a change in the national policy is underway, moving towards a lesser burden on the environment, which is also in line with social expectations. The future plans include only gas-steam and nuclear units, along with the development of photovoltaic and offshore wind power plants (Gawlik and Mokrzycki 2019). These projections could be very reassuring.

However, upon comparing these assumptions with reality, the conclusions are rather bleaker. The lack of adequate generation capacity is a serious problem for Poland. On the basis of the prospective scenarios, it can be seen that the next decades of the 21 st century will mean an increase in demand for electricity (Rosicki 2017; Szczerbowski and Ceran 2017).

The dialectic confrontation between the two government strategies - the current PEP 2030 and the projected PEP 2040 - shows that the capacity problem has not been resolved at a strategic level. In the perspective until 2030, both strategies assumed a moderate increase in energy production from lignite. However, the PEP 2040 provides for a significant reduction in the share of this raw material in energy production over the last decade (until 2040). Both documents also assumed the construction of a nuclear power plant. However, PEP 2040, for the period up to 2030, does not foresee a share of nuclear power in the energy mix. According to this document, 
the first nuclear power plant is not scheduled to be completed until 2033. In the meantime, the current PEP 2030 assumes nuclear energy production from 2020.

Although appropriate analyses were developed in 2013-2016 to provide a substantive basis for a new policy strategy, the draft PEP 2040 was only submitted for public consultation in November 2018. An additional problem is that it did not contain an assessment of the implementation of the state's energy policy for the previous period, as required by the Energy Law of 1997 (Act 1997). In the absence of the current Polish energy policy, the relevant minister has not developed other documents defining the strategy for the development of national generation capacities. As a result, all investment plans in the electricity sector, as well as projects in progress, are subject to both profitability and regulatory risks. One of the risk factors is the lack of information about the future structure of the energy mix and a coherent and evaluable action plan, coordinated with stakeholders, indicating the path to the planned status.

In light of this, it seems obvious that the lack of a coherent vision on the reduction of coal consumption, while ignoring the issue of missing generation capacities, may constitute a serious barrier for Poland in the process of the pro-ecological transformation of the energy sector and the achievement of the objectives of the new European Green Deal.

\section{Increase in the importance of RES in the energy balance of Poland - from plans to reality}

Renewable energy sources have a potential that is important both from a technological and political point of view (Ruszel 2017). Their use is becoming a global megatrend (Deloitte 2016). The promotion of renewable technologies in the energy balances of Member States is fully accepted and promoted by the European Union, which both in its policies (EC 2010, 2013, 2015, 2015a, 2019; Mrozowska 2016; Młynarski 2019), as well as in primary and secondary legislation (TFEU, Title XXI), encourages Member States to use RES. The RES revolution is happening at different speeds in different countries. Their use depends on a number of factors, which could be categorized collectively as: economic and social, legislative and - to a lesser extent - technological.

The EU Directive on RES (Directive 2009/28) obliged Poland to increase the share of RES in the energy mix to a minimum of $15 \%$ of energy from renewable sources in the gross final energy consumption by 2020. However, the requirements for RES continue to increase. Under the new EU legislation, the share of RES in gross energy consumption is to be $32 \%$ by 2030 (Directive 2018/2001).

Moreover, on the basis of regulations adopted by the EU, in order to implement the EU energy and climate policy in 2021-2030, as part of the so-called Winter Package, Member States were obliged to prepare their own national strategies in this respect (National Energy and Climate Plans, NECPs). Poland has drawn up such a strategy entitled "The National Energy 


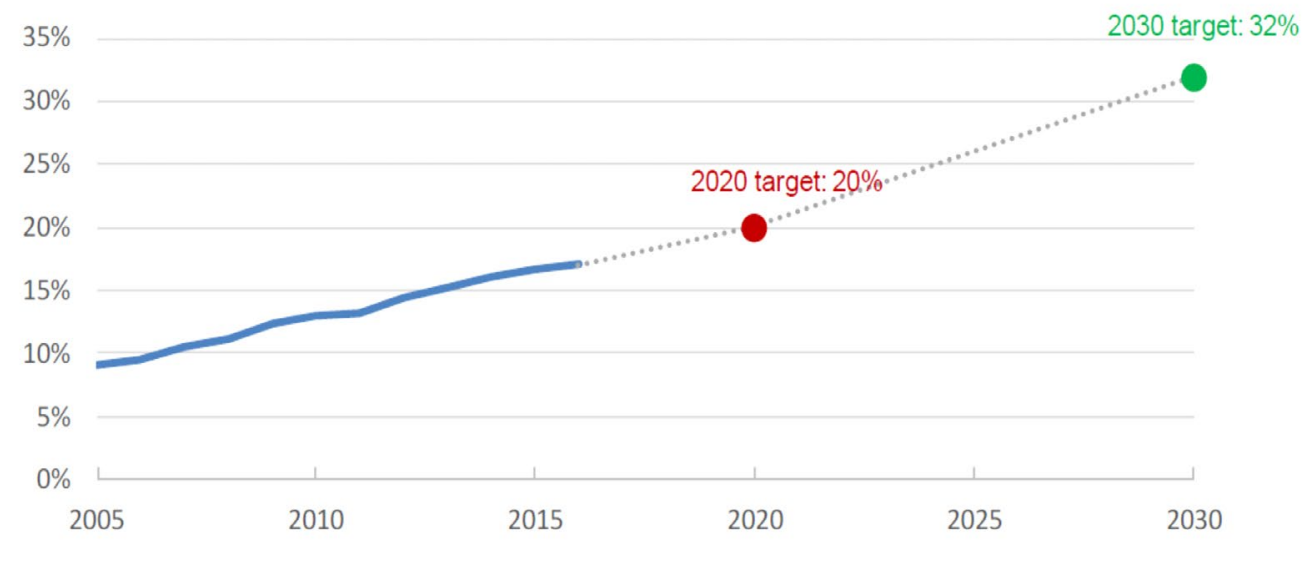

Fig. 4. Share of renewable energy in gross final energy consumption in the EU

Source: Eurostat SHARES

Rys 4. Udział energii odnawialnej w końcowym zużyciu energii brutto w UE

and Climate Plan 2021-2030" (NECP 2019) and submitted it to the European Commission for notification in December 2019. According to its content, "energy production from renewable sources is an important part of the efforts towards de-carbonising, as well as to diversify and meet growing energy demand". It is "an expression of care for the natural environment and a response to the need to promote sustainable development" (NECP 2019). The Act on Renewable Energy Sources of 2015 (Act 2015) is indicated in the document as the basic legal act aimed at promoting RES in Poland. It was stressed that it creates instruments to support the development of the RES. These include: an auction system for most of the currently dominant RES technologies, transitional solutions to the green certificate system, support for prosumers, as well as all the rules and conditions for the operation of electricity generation, agricultural biogas, heat and bioliquids, as well as instruments for their systemic support. Additionally, it was indicated that the Polish government supports the development of distributed energy, especially cluster initiatives and energy cooperatives.

The strategic assumptions related to the development of renewable energy sources in the EU clash with a difficult reality in Poland. There are many systemic challenges of a legal, technological and social nature.

The legal challenges include changes in the scope of the existing laws, which more or less negatively affect the development of the RES. For example, the restrictive restrictions imposed by the Act on Wind Energy Investments of May 20, 2016 (Act 2016) were a significant hindrance to wind energy development. As a result of these changes, foreign investors are filing claims that will have financial consequences in the coming years that are difficult to estimate.

Another example of changes in the area of law concerns the amendment to the Act on RES in the field of dispersed energy. In 2016, activities were undertaken to develop the concept of energy clusters, namely civil law agreements that link: (1) a power generator, (2) a distributor 
and (3) consumers (Tchórzewski 2016). The activity of the cluster is not clearly set out in the act and allows it to be seen in various configurations. For example, within a cluster, electricity can theoretically be traded, which means that a member of the cluster, or its coordinator, can buy energy from at least one generator and sell it to an interested customer. It is also possible to imagine a situation in which electricity distribution is carried out within the cluster, although it is actually a task reserved for distribution network operators and entities that have obtained that status through a concession granted by the president of the Energy Regulatory Office.

In view of the above, the conclusion is that the new law, instead of facilitating the task of RES investors, has introduced many doubts. Hence the suggestions from the renewable energy industry to clarify the law in detail, particularly with regard to: the support system and the structure of the cluster, its main functions, as well as the target audience. This would allow it to build clear business rules and create a basis for making effective investments for entities that see their place in this industry (Tomaszewski 2019).

The technical problems include issues of adapting the existing infrastructure to new solutions related to the connection of RES installations, both with regard to large-scale RES (wind and photovoltaic farms) and at the prosumer level (Gawlik et al. 2015; Sowa 2019). In particular, there is a need for the expansion and modernization of medium and low voltage power networks, as well as the construction of substations. However, achieving these objectives requires significant financial outlays, which will largely be borne by the distribution companies. Although they may count on support from EU funds in this area, these expenses will constitute a significant burden on the operating budget of the companies involved, and this may result, in the future, in the costs being passed on to consumers, namely to energy consumers (Azarova et al. 2019).

As for social issues, it should be stressed that, despite the general support of Poles for RES, the NIMBY syndrome seems to be a serious problem. The lack of zoning plans in more than $60 \%$ of Poland's areas has led to a situation where local communities often do not actively participate in shaping their environment and perceive the development of RES (especially wind farms) as a threat to the residual value of their properties, as well as an element contributing to the deterioration in the quality of life and worsening the landscape values of their small homelands (Berlińska 2016; Aaen et al. 2015).

Important cognitive research in this area was conducted by Bednarek-Szczepańska and Dmochowska-Dudek (2015). As a result of press searches, the researchers obtained information on 499 conflicts showing features of the NIMBY syndrome, taking place in rural areas and small towns in Poland in the period from January 2007 to March 2014. As they pointed out, "the investments were protested against, which were very diverse in terms of function, the size of the object, the type of investor, the scale and nature of the impact. The most numerous group, comprising 351 technical infrastructure facilities, includes facilities related to energy generation and supply (e.g. power plants, biogas plants and power grids - fig. below)".

To sum up, instead of uniting people in the spirit of ecological energy production, RES is often a symbol of social divisions, where on the one hand there are beneficiaries, including tenants, who profit from new installations, and on the other hand there are the other residents, who 


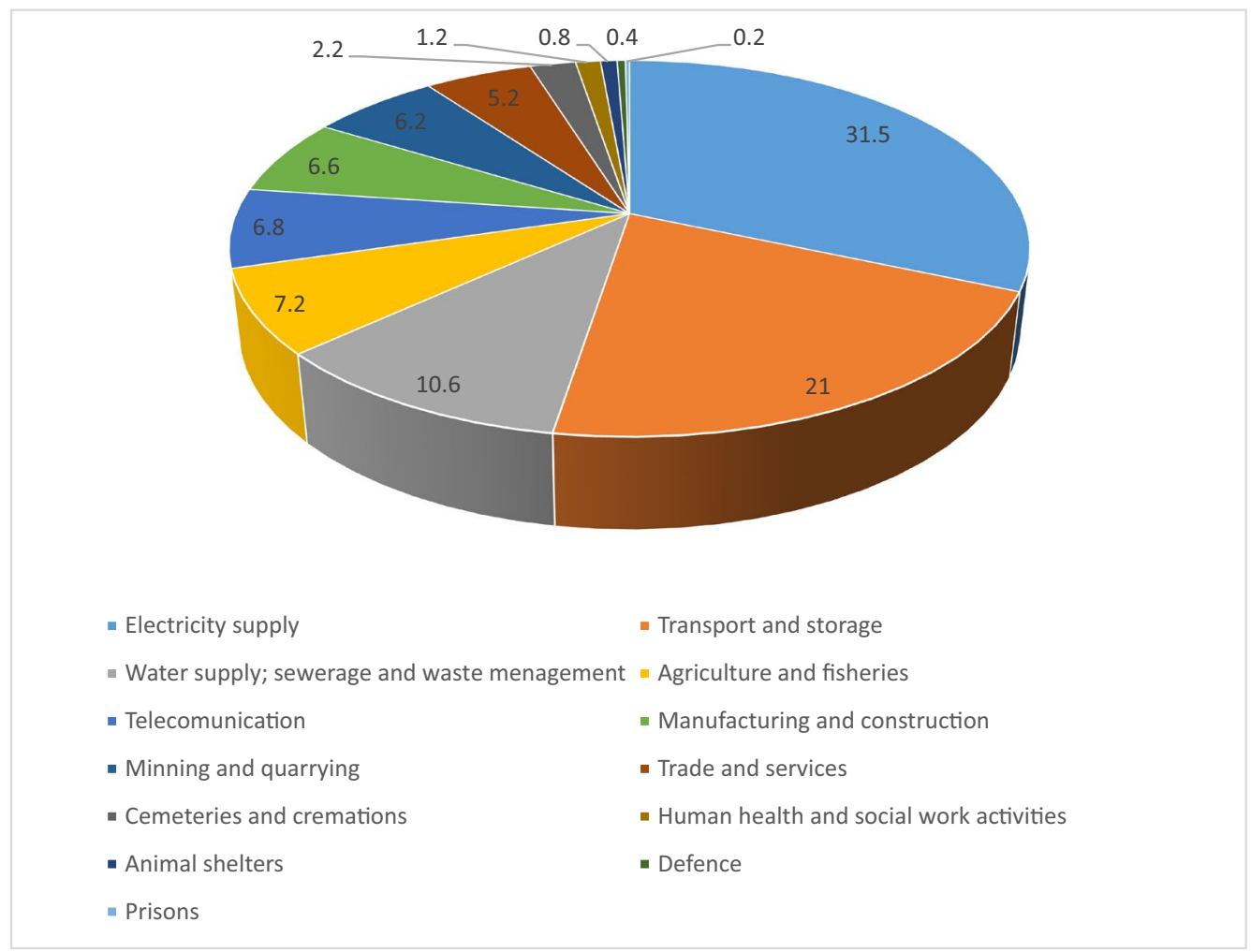

Fig. 5. NIMBY objects by category

Source: Bednarek-Szczepańska and Dmochowska-Dudek 2015

Rys. 5. Obiekty NIMBY według kategorii

believe that tax revenues to the municipalities' budgets are too little benefit for them as a result of the state's energy transformation (Lucki and Misiak 2010; Wolsink 2018).

The unfavorable balance of systemic problems related to the implementation of RES in Poland is reflected in the NIK Report Development of the Renewable Energy Sector of August 2018. It concludes that achieving the target of a $15 \%$ share of energy from renewable sources in the total gross energy consumption in 2020 could be at risk. The following factors that had a negative impact on the development of renewable energy were identified: lack of a consistent state policy towards renewable energy sources, delays in issuing implementing regulations, and the lack of a sufficiently stable and friendly legal environment ensuring security and predictability of investments in the RES, in particular in the electricity sector (NIK 2018). 


\section{Conclusions}

In conclusion, the European Union's energy and climate policy is undoubtedly an ambitious challenge, both for the Community and from the perspective of individual Member States (Ruszkowski 2010; Tomaszewski 2018a). Given the climate priorities, it is important to consider whether the situation in Europe and the world after the coronavirus pandemic is over will not cause these objectives to be postponed or temporarily suspended (Kloc 2020).

For Poland, this challenge seems to be particularly difficult to meet, not only because of the economic problems associated with the pandemic, but above all because of the current model of energy production - namely our dependence on fossil fuels, especially hard coal and lignite, and the insufficient rate of implementing renewable sources in the national energy mix. For example, the NIK report of 2018 indicates the difficult situation of the RES sector in Poland and leaves no doubts about the future of this technology in the Polish energy mix. The auditors' conclusions indicate that achieving the target of a $15 \%$ share of energy from renewable sources in the total gross energy consumption in 2020 could be jeopardized. This is not a surprising conclusion, but certainly a very disappointing one, especially in the context of the European Union's expectations towards Poland, but also taking the expectations of the Polish society into account.

However, these problems do not mean that it is impossible to follow the path set out by the European Commission in the European Green Deal. This should be done in both strategic and practical terms. In the long term, they would make it possible to minimize the existing weaknesses.

In the strategic dimension, the key action seems to be the adoption of a new global strategy for the sector, namely the Polish Energy Policy until 2040 by the Council of Ministers. It should be agreed with stakeholders and accepted by the industry.

Another sine qua non element seems to be the development, together with other important energy market participants, of a plan to replace the decommissioned generation units with new units, according to the adopted target energy mix.

In addition, it is also important to introduce instruments for monitoring and evaluating the regulatory and economic support for modernization investments and the construction of generation capacity.

Referring to the research assumption indicated in the introduction, Poland has real possibilities of effectively implementing the provisions of the European Green Deal, provided, however, that it: a) implements an appropriate strategy of action in the area of the coal sector by systematically reducing this raw material in the energy balance, and b) brings about a rapid increase in the potential of RES in the national economy. 


\section{References}

AaEn et al. 2015 - Aaen, S.B., Kerndrup, S. and Lyhne, I. 2016. Beyond public acceptance of energy infrastructure: How citizens make sense and form reactions by enacting networks of entities in infrastructure development. Energy Policy Vol. 96, pp. 576-586.

Act 1997. Energy Law of April 10, 1997 (Prawo energetyczne z dnia 10 kwietnia 1997 r.), Dz.U. 2019.755 consolidated (in Polish).

Act 2015. Act on renewable energy sources of February 20, 2015 (Ustawa o odnawialnych źródtach energii $z$ dnia 20 lutego 2015), Dz.U. 2020.261 consolidated (in Polish).

Act 2016. Act on investments in wind farms of May 20, 2016 (Ustawa o inwestycjach w zakresie elektrowni wiatrowych z dnia 20 maja 2016), Dz.U. 2019.654 consolidated (in Polish).

Azarova et al. 2019 - Azarova, V., Cohen, J., Friedl, Ch. and Reichl, J. 2019. Designing local renewable energy communities to increase social acceptance: Evidence from a choice experiment in Austria, Germany, Italy, and Switzerland. Energy Policy Vol. 132, pp. 1176-1183.

Bednarek-SzCZePańSKa, M. and DMOChowsKa-Dudek, K. 2015. The spatial dimension to NIMBY syndrome in Poland's rural areas and small towns (Przestrzenny wymiar syndromu NIMBY na wsi i w matych miastach $w$ Polsce). Przeglad Geograficzny No. 87, Iss. 4, pp. 683-703 (in Polish).

BERLIŃSKa, P. 2016. Political and social conditions for the development of the wind energy sector in the light of the design of regional energy markets in Poland (Polityczne i spoleczne uwarunkowania rozwoju sektora energetyki wiatrowej $w$ świetle projektu regionalnych rynków energii $w$ Polsce). [In:] D. Smyrgała ed. Between regional energy markets and technology - the future of the energy sector in Poland (Między regionalnymi rynkami energii a technologia - przyszłość sektora energetycznego w Polsce). Warszawa: Collegium Civitas Press, pp. 39-46 (in Polish).

Cohen et al. 2014 - Cohen, J.J., Reichl, J. and SCHMidThaleR, M. 2014. Re-focussing research efforts on the public acceptance of energy infrastructure: A critical review. Energy Vol. 76, pp. 4-9.

DELOITTE 2016. Polish Power Sector Riding on the Wave of Megatrends, Warszawa: Deloitte and Forum Analiz Energetycznych.

Devine-Wright, P. 2019. Community versus local energy in a context of climate emergency. Nature Energy Vol. 4, pp. 894-896.

Directive 2009/28 of the European Parliament and of the Council of 23 April 2009 on the promotion of the use of energy from renewable sources and amending and subsequently repealing Directives 2001/77/ EC and 2003/30/EC, OJ L 140, 5.6.2009, pp. 16-62.

Directive 2018/2001 of the European Parliament and of the Council of 11 December 2018 on the promotion of the use of energy from renewable sources, OJ L 328, 21.12.2018, pp. 82-209.

EC 2010. European Commission. Communication: Energy 2020. A strategy for competitive, sustainable and secure energy, COM (2010) 639.

EC 2013. European Commission. Green Paper: A 2030 framework for climate and energy policies, COM (2013) 169.

EC 2015. European Commission. Communication: State of the Energy Union, COM (2015) 572.

EC 2015a. European Commission. Communication: A Framework Strategy for a Resilient Energy Union with a Forward-Looking Climate Change Policy, COM (2015) 80.

EC 2019. European Commission. Communication: The European Green Deal, COM (2019) 640.

Eurostat SHARES. [Online] https://ec.europa.eu/eurostat/web/energy/data/shares [Accessed: 2020-04$-15]$.

GaWlik et al. 2015 - Gawlik, L., Szurlej, A. and Wyrwa, A. 2015. The impact of the long-term EU target for renewables on the structure of electricity production in Poland. Energy Vol. 92, Part 2, pp. 172-178. 
Gawlik, L. and Mokrzycki, E. 2019. Changes in the Structure of Electricity Generation in Poland in View of the EU Climate Package. Energies Vol. 12, DOI: 10.3390/en12173323.

KLOC, I. 2020. European Green Deal may wait while the coronavirus pandemic is ongoing (Europejski Zielony Ład może poczekać, gdy trwa pandemia koronawirusa). [Online] https://biznesalert.pl/europejski-zielony-lad-koronawirus-apel-izabela-kloc-energetyka-klimat-srodowisko/ [Accessed: 2020-04-19] (in Polish).

KsIĘżopolski, K. 2015. Poland's energy and climate policy in 2014-2015 (Polityka energetyczno-klimatyczna Polski w latach 2014-2015). Warszawa: Instytut Badań nad Bezpieczeństwem, Energetyką i Klimatem, 317 pp. (in Polish).

ŁUCKI, Z. and MisIAK, A. 2010. Energy and society. Sociological aspects (Energetyka a spoleczeństwo. Aspekty socjologiczne). Warszawa: Wydawnictwo Naukowe PWN, 264 pp. (in Polish).

MarczUK, K.P. 2014. Determinants of social security (Determinanty bezpieczeństwa spolecznego). [In:] S. Sulowski, M. Brzeziński eds. Three dimensions of modern security (Trzy wymiary wspótczesnego bezpieczeństwa). Warszawa: Elipsa, pp. 148-157 (in Polish).

MŁYNARSKI, T. 2019. The European Union in the process of energy transformation (Unia Europejska w procesie transformacji energetycznej). Krakowskie Studia Międzynarodowe Vol. 16, Iss. 1, pp. 31-44 (in Polish).

Morris, C. and Junguohann, A. 2016. Energy Democracy. London: Palgrave Macmillan, 437 pp.

MrozowsKa, S. 2016. Energy policy of the European Union. Between strategy, lobbying and participation (Polityka energetyczna Unii Europejskiej. Między strategia, lobbingiem a partycypacja). Kraków: Libron, 360 pp. (in Polish).

NECP 2019. National Energy and Climate Plan 2021-2030 (Krajowy plan na rzecz energii i klimatu na lata 2021-2030), version 4.1./18.12.2019, Warszawa: Ministry of State Assets (Ministerstwo Aktywów Państwowych). [Online] https://www.gov.pl/web/aktywa-panstwowe/krajowy-planna-rzecz-energii-i-klimatu-na-lata-2021-2030-przekazany-do-ke [Accessed: 2020-04-06] (in Polish).

NIK 2018. Supreme Audit Office. Development of the renewable energy sector (Rozwój sektora odnawialnych źródet energii). Sign. No 171/2017/P/17/020/KGP. [Online] https://www.nik.gov.pl/plik/ id,18357,vp,20955.pdf [Accessed: 2020-04-17] (in Polish).

NIK 2019. Supreme Audit Office. Investments in Electricity Generative Power in the years 2012-2018 (Inwestycje w moce wytwórcze energii elektrycznej w latach 2012-2018). Sign. No 26/2019/P/18/018/ KGP. [Online] https://www.nik.gov.pl/plik/id,21644,vp,24294.pdf [Accessed: 2020-04-17] (in Polish).

Nyga-Łukaszewska et al. 2020 - Nyga-ŁukaszewsKa H., Aruga K. and Stala-Szluga K. 2020. Energy Security of Poland and Coal Supply: Price Analysis. Sustainability Vol. 12, p. 1-18, DOI: 10.3390/ su12062541.

PEP 2030 - Polish Energy Policy until 2030 (Polityka energetyczna Polski do 2030 roku). M.P. 2010 Vol. 2, pos. 11 (in Polish).

PEP 2040. Polish Energy Policy until 2040 (Polityka energetyczna Polski do 2040 roku). [Online] https:// www.gov.pl/web/aktywa-panstwowe/zaktualizowany-projekt-polityki-energetycznej-polski-do-2040-r [Accessed: 2020-04-17] (in Polish).

Rosicki, R. 2017. Poland's energy policy: main problems and forecasts. Środkowoeuropejskie Studia Polityczne Vol. 2, pp. 59-87.

Ruszel, M. 2016. The energy security paradigm (Paradygmat bezpieczeństwa energetycznego). [In:] J. Gryz ed. Outline of the theory of state security (Zarys teorii bezpieczeństwa państwa), Warszawa: Akademia Obrony Narodowej, 347 pp. (in Polish).

Ruszel, M. 2017. Climate diplomacy as instrument of Germany's energy policy (Dyplomacja klimatyczna instrumentem polityki energetycznej RFN). Studia Politica Germanica Vol. 2, pp. 83-97 (in Polish).

Ruszkowski, J. 2010. Transnationality in the EU political system (Ponadnarodowość w systemie politycznym UE). Warszawa: Wolters Kluwer, 443 pp. (in Polish). 
SowA, S. 2019. The capacity market and its impact on the development of distributed energy sources. Polityka Energetyczna - Energy Policy Journal Vol. 22, Iss. 4, pp. 65-80.

Szczerbowski, R. and Ceran, B. 2017. Poland's Energy Policy in the aspect of the challenges of the $21^{\text {st }}$ century (Polityka energetyczna Polski w aspekcie wyzwań XXI wieku). Polityka Energetyczna - Energy Policy Journal Vol. 20, Iss. 3, pp. 17-28 (in Polish).

TCHÓRZEWSKI, K. 2016. Energy clusters - a mechanism to stabilize the participation of RES in the energy system, speech of the Minister of Energy during the conference Concept of Energy Clusters in the Operational Program Infrastructure and Environment 2014-2020 (Klastry energii - mechanizm stabilizacji udziatu OZE w systemie energetycznym, wystapienie Ministra Energii podczas konferencji Koncepcja Klastrów Energii w Programie Operacyjnym Infrastruktura i Środowisko 2014-2020), Warszawa, 16.12.2016 (in Polish).

TFUEU, Treaty on the Functioning of the European Union (Consolidated version 2016), OJ C 202, 07.06.2016, Title: XXI.

Tomaszewski, K. 2018. Multi-level governance in the EU Energy Policy (Zarzadzanie wielopoziomowe w polityce energetycznej Unii Europejskiej). Polityka Energetyczna - Energy Policy Journal Vol. 21, Iss. 1, pp. 21-36 (in Polish).

TomaszewsKi, K. 2018a. Energy solidarity in the European Union in the context of the particular interests of the Member States. Polityka Energetyczna - Energy Policy Journal Vol. 21, Iss. 2, pp. 5-18.

Tomaszewski, K. 2019. Energy Clusters in Poland: Towards Improving Energy Efficiency. Concepts and Conditions (Klastry energii w Polsce - w kierunku poprawy bezpieczeństwa energetycznego. Koncepcje i uwarunkowania). Państwo i Prawo Vol. 4 (878), pp. 68-78 (in Polish).

United Surveys for RMF FM and Dziennik Gazeta Prawna. [Online] https://www.rmf24.p1/fakty/polska/ news-sondaz-ponad-60-proc-polakow-jest-za-rezygnacja-z-energetyki,nId,4306001 [Accessed: 2020-04-15] (in Polish).

Wolsink, M. 2018. Co-production in distributed generation: Renewable energy and creating space for fitting infrastructure within landscapes. Landscape Research Vol. 43, pp. 542-561.

Krzysztof Tomaszewski

\author{
Polska droga w kierunku realizacji założeń nowego \\ Europejskiego Zielonego Ładu - wyzwania i zagrożenia \\ dla krajowej polityki energetycznej
}

\title{
Streszczenie
}

Unia Europejska ma aspiracje do realizowania ambitnej polityki klimatycznej. Sektor energetyczny jest kluczowym narzędziem dla zagwarantowania sukcesu w tej dziedzinie. Jednocześnie zbyt wygórowane cele mogą stanowić poważny problem dla poszczególnych państw członkowskich. Celem artykułu jest analiza możliwości, jakimi dysponuje polski sektor energetyczny w kontekście zakładanych celów neutralności klimatycznej UE do 2050 roku. 
Analizowany problem badawczy dotyczy w szczególności dwóch obszarów uznawanych za strategiczne dla Polski: sektora węglowego oraz sektora odnawialnych źródeł energii. Rola pierwszego powinna być w najbliższych dekadach znacząco ograniczona, podczas gdy pozycja drugiego powinna ulec zasadniczemu wzmocnieniu. Zestawienie tych wyzwań z polskimi realiami gospodarczymi, społecznymi oraz technologicznymi stanowi zasadniczy przedmiot analizy w niniejszym tekście. W wymiarze metodologicznym wykorzystana zostanie metoda analizy systemowej z elementami podejścia decyzyjnego. Pozwoli to efektywnie zoperacjonalizować na płaszczyźnie badawczej najważniejsze problemy oraz wyzwania związane z koniecznością niezbędnych dostosowań, jakie należy podjąć w Polsce, aby osiągnąć priorytety zakładane przez Unię Europejską.

Hipoteza artykułu wskazuje, że Polska jest w stanie skutecznie sprostać europejskim celom klimatycznym, aczkolwiek realizacja tego wyzwania wymaga zdecydowanych działań ze strony rządu, jak również adekwatnej odpowiedzi ze strony inwestorów oraz społeczeństwa. W tym celu potrzebne jest podjęcie odpowiednich działań zarówno na poziomie strategicznym, jak również operacyjnym.

SŁowA KLUCZOWE: Zielony Ład UE, polityka energetyczna, węgiel, odnawialne źródła energii, koronawirus 